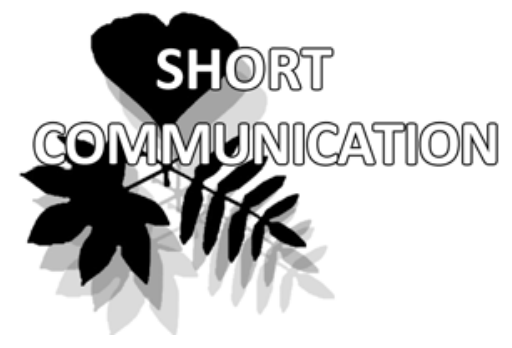

Yu Ito $1,2, *$

e-mail: yu.ito@canterbury.ac.nz

Tetsuo Ohi-Toma ${ }^{1}$

e-mail: ooi@ns.bg.s.u-tokyo.ac.jp

Anna V. Skriptsova ${ }^{3}$

Michihiro Sasagawa ${ }^{4}$

Norio Tanaka ${ }^{5}$

e-mail: ntanaka@kahaku.go.jp

Jin Murata

e-mail: murata@ns.bg.s.u-tokyo.ac.jp

${ }^{1}$ Botanical Gardens, The University of

Tokyo, Tokyo, Japan

${ }^{2}$ University of Canterbury, Christchurch, New Zealand

${ }^{3}$ A.V. Zhirmunsky Institute of Marine Biology FEB RAS, Vladivostok, Russia

${ }^{4}$ Niigata Prefectural Niigata Minami High School, Niigata, Japan

${ }^{5}$ Tsukuba Botanical Garden, National Museum of Nature and Science, Tsukuba, Japan

* corresponding author

Manuscript received: 01.01.2014

Review completed: 10.02.2014

Accepted for publication: 14.02.2014

\section{Ruppia megacarpa (Ruppiaceae): a new species to the floras of Japan, Korea, and Russia}

Yu Ito ${ }^{1,2, *}$, Tetsuo Ohi-Toma ${ }^{1}$, Anna V. Skriptsova ${ }^{3}$, Michihiro Sasagawa ${ }^{4}$, Norio Tanaka ${ }^{5}$, and Jin Murata ${ }^{1}$

\begin{abstract}
A B S T R A C T
Ruppia L. is the only genus in Ruppiaceae that is primarily distributed in brackish water. A previous molecular phylogenetic work revealed that 2 non-flowering Ruppia specimens from Japan and Russia were genetically identical to Ruppia megacarpa R. Mason, a species previously known only from Australasia. To update East Asian floras, our study examined flowering specimens of putative R. megacarpa from East Asia, including the localities where the non-flowering specimens originated, and assessed their morphological characters by comparing them with those of the R. megacarpa holotype from New Zealand as well as morphological data obtained from the protologue and other systematic works. The three East Asian specimens exhibited slightly different quantitative morphology compared with the holotype; however, the values were mostly within the species variation. The species distribution was accordingly revised.
\end{abstract}

Keywords

Aquatic plants, Japan, Korea, Ruppia megacarpa, Ruppiaceae, the Russian Far East

\section{P E 3 Ю M E}

Ито Ю, Охи-Тома Т., Скрипцова А.В., Сасагава М., Танака Н., Мурата Аж. Ruppia megacarpa (Ruppiaceae) - новый виА ААя фмор Японии, Кореи и России

Ruppia L. - единственный род в семействе Ruppiaceae, чьи преАставители распространяются преимущественно в солоноватой воде. Предшествующие исследования по молекулярной филогении рода показали, что 2 нецветущих образца Rирріа из Японии и России были генетически илентичны Ruppia megacarpa - вилу, ранее известному только из Австралии. Аیя уточнения виАового состава рода в Восточной Азии были исследованы образцы цветущих растений предполагаемого вила P. megacarpa, в том числе собранные в местообитаниях, откуда взяты нецветущие экземпляры, а также бым проведен сравнительный анализ их морфологических признаков с гомотипом P. megacarpa из Новой Зеландии и с морфологическими Аанными, приводимыми в протологах Аругих систематических работ. Три образца с Восточной Азии имеют незначительные количественные отличия в морфологии в сравнении с голотипом, однако, отклонения не выходят за рамки внутривидовой изменчивости. Таким образом распределение Аанного вида существенно уточнено.

Ключевые слова

водные растения, Япония, Корея, Ruppia megacarpa, Ruppiaceae, российский Аальний Восток

\section{N T RO D U C T I O N}

Ruppia L. is the only genus from the aquatic family Ruppiaceae, which is primarily distributed in brackish waters. The taxonomic confusion surrounding this group resulted from of its simple morphology, polyploidy, and worldwide distribution, preventing achievement of consensus regarding the infrageneric taxonomy (reviewed in Ito et al. 2010). Molecular phylogenetic analyses using plastid and nuclear DNA markers have dramatically resolved this issue and proposed a new classification of three morphologically and genetically distinct species: Ruppia megacarpa R. Mason (1967), R. polycarpa R. Mason (1967), and R. tuberosa Davis \& Tomlinson (1974). In addition, a morphologically diverged but genetically clustered species complex, R. maritima L. (1753), has been identified (Ito et al. 2010).

Phylogenetic analyses of some non-flowering specimens from East Asia revealed genetic sequences identical to Ruppia megacarpa from Australia (Ito et al. 2010). This species was described in New Zealand (Mason 1967) with larger fruits, well-coiled peduncles, branched to zigzag stems, and bidentate to truncate leaf tips, and believed to be endemic to the southern region of Australasia (Jacobs \& Brock 1982, 2009), and thus, not listed in East Asian floras.

The aim of this study was to add Ruppia megacarpa to East Asian floras through morphological examination of relevant specimens from the area. For this purpose, herbarium surveys 
were conducted to locate flowering specimens of putative R. megacarpa from East Asia, including those localities where genetically confirmed, non-flowering specimens were collected (Ito et al. 2010). Morphological evaluations were conducted, and the results were compared with the $\mathrm{R}$. megacarpa holotype and the specimen reported in the protologue as well as that from other taxonomic literature. Based on these findings, $R$. megacarpa distribution was revised.

\section{MATERIALS AND METHODS}

\section{Taxon sampling}

Herbarium surveys were conducted to locate flowering specimens of putative Ruppia megacarpa, focusing on Japan and Russia where non-flowering R. megacarpa were previously collected (Ito et al. 2010). Two flowering specimens were located: Sasagawa 5380-a (Niitsu Shokubutu Shiryoushitu) and Skriptsova-2013-001 (Institute of Marine Biology, Far Eastern Branch of the Russian Academy of Sciences). To understand the actual distribution in East Asia, additional herbarium surveys were conducted that focused on other East Asian countries. A relevant specimen from Korea was identified (Faurie no. 225 [KYO]; Fig. 1). The R. megacarpa holotype from New Zealand was included as a comparative specimen (J. Clarke 150818A [CHR]).

\section{Morphological assessment}

The three East Asian flowering specimens of Ruppia megacarpa and the holotype from New Zealand were examined with special reference to reproductive characters and compared with those reported in the protologue and other taxonomic literatures (Mason 1967, Jacobs \& Brock 1982, 2009). The length of peduncles, pedicels, and leaves of each specimen were measured using the ImageJ software (Abràmoff et al. 2004).

\section{RES U LTS}

The flowering Ruppia megacarpa specimens from East Asia exhibited branched-stem pattern, bidentate leaf tips, leaves of 5.5-14.5 cm length, well-coiled peduncles 10.5-
$20.1 \mathrm{~cm}$ in length, fruits $2.9-3.5 \mathrm{~mm}$ in size, if matured, and four carpels (Table 1). The morphological characters obtained from the holotype of $R$. megacarpa included: branched-stem pattern, bidentate leaf tips, leaves of 4.6$19.6 \mathrm{~cm}$ length, well-coiled peduncles $17.5-33.4 \mathrm{~cm}$ in length, fruits $3-3.8 \mathrm{~mm}$ in size, if matured, and four carpels (Table 1).

\section{DISCUSSION}

The flowering specimens of Ruppia megacarpa from East Asia exhibited diagnostic characteristics of the species, such as bidentate leaf tips, four carpels, and a larger fruit size (Mason 1967, Jacobs \& Brock 1982, 2009, Zhao \& Wu 2008). Some morphological differences were observed in quantitative characters between the three East Asian specimens and holotype, such as peduncle length and fruit size. However, these values were within the variations previously reported. Thus, the distribution of $R$. megacarpa was revised to include Japan, Korea, and Russia. Note that China is not included, even though $R$. megacarpa is recently reported (Yu et al. 2014) because one of the included specimens is described as having "an abortive inflorescence with anthers lacking pollens; the carpels were shrunken". Given that a sterile hybrid of R. megacarpa is reported from Hokkaido, Japan (Ito et al. 2010), which has only vegetative parts, this Chinese specimens might be not R. megacarpa but rather the hybrid.

\section{Taxonomic treatment}

Ruppia megacarpa R. Mason (1967; 525, f. 3).

Type: NEW ZEALAND, Taumatu: drift in Lake Ellesmere, 9 Feb. 1966, J. Clarke 150818 A (holotype CHR!).

Chromosome number: $2 n=20$ (New Zealand [Mason 1967, Beuzenberg \& Hair 1983]; Australia [Jacobs \& Brock 1982, Snoeijs \& Van der Ster 1983, Ito et al. 2010]; Japan [Ito et al. 2010]).

Distribution: Australasia (Australia, New Zealand), East Asia (Japan, Korea, Russia) (Fig. 2).

Additional specimens examined: JAPAN, Niigata, Kamoko lake, 6 Jun. 2006 (Niitsu Shokubutu Shiryoushitu:

Table 1. Morphological comparisons between the holotype of Ruppia megacarpa and East Asian specimens

\begin{tabular}{|c|c|c|c|c|c|}
\hline Voucher & $\mathbf{N} / \mathbf{A}^{1}$ & $\begin{array}{l}\text { J. Clarke } \\
150818 A\end{array}$ & Sasagawa 5380-a & $\begin{array}{l}\text { Faurie no. } \\
\quad 225\end{array}$ & Skriptsova-2013-001 \\
\hline Country of origin & N/A & New Zealand & Japan & Korea & Russia \\
\hline Stem pattern & branched to zigzag & zigzag & branched & branched & branched \\
\hline Leaf length $(\mathrm{cm})$ & $5-25$ & $4.6-20.0$ & $5.5-14.5$ & $3.2-7.7$ & $10.5-12.5$ \\
\hline Leaf tip shape & $\begin{array}{l}\text { bidentate to } \\
\text { truncate }\end{array}$ & bidentate & bidentate & bidentate & bidentate \\
\hline Peduncle length (mm) & $10-30$ & $17.5-33.4$ & $10.5-20.1$ & $12.2-15.4$ & 12.2 \\
\hline Fruit size $(\mathrm{mm})$ & $(3-) 4(-5)$ & $3.2-4.9$ & $3-3.8$ & $3-3.5$ & $\mathrm{~N} / \mathrm{A}^{2}$ \\
\hline Carpel number & $(2-) 4(-6)$ & 4 & 4 & 4 & 4 \\
\hline
\end{tabular}

${ }^{1}$ After Mason (1967), Jacobs \& Brock (1982; 2009), Zhao \& Wu (2008)

${ }^{2}$ No mature fruits are observed 


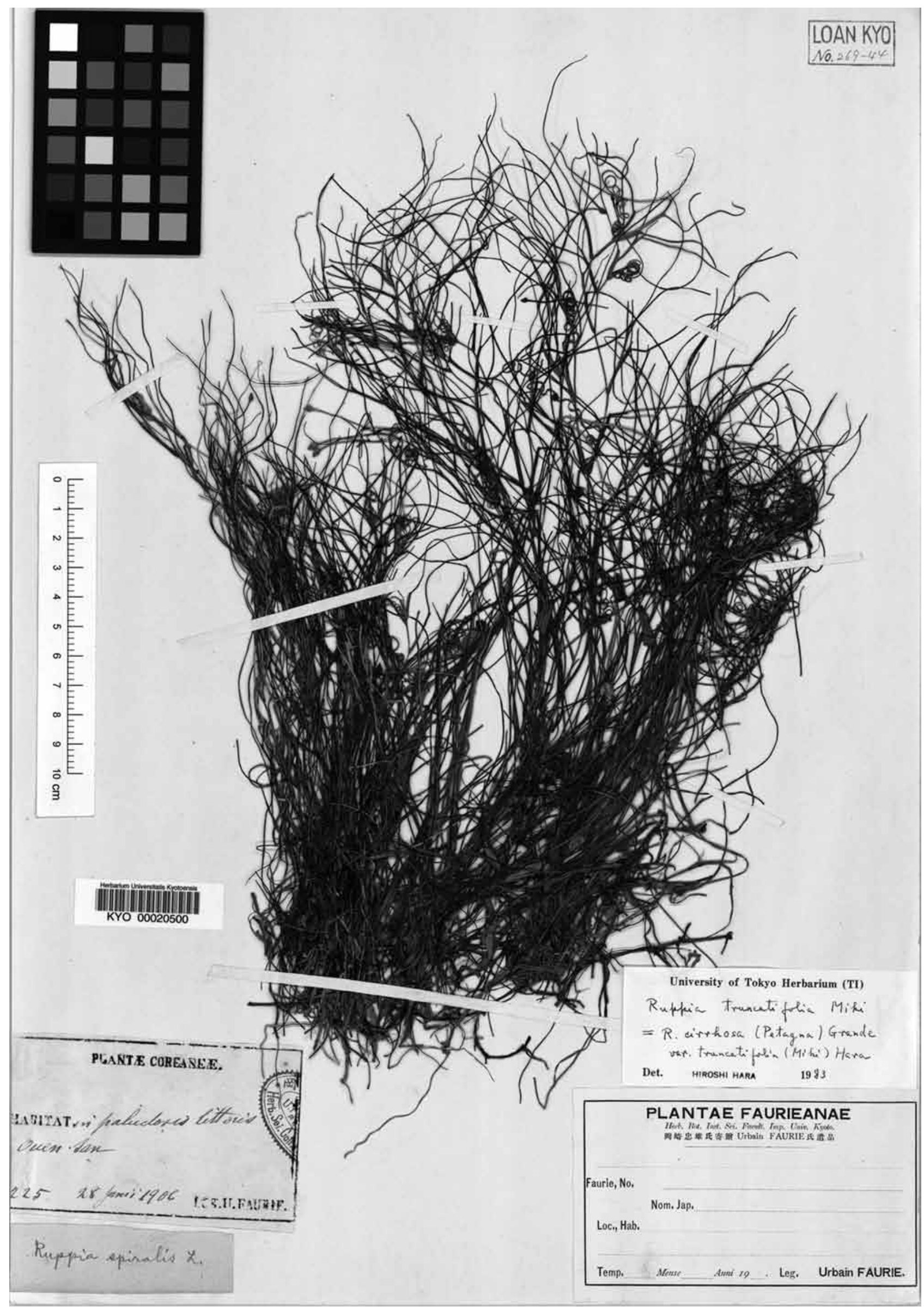

Figure 1 Voucher specimen of Ruppia megacarpa from Korea (Faurie no. 225; KYO). 


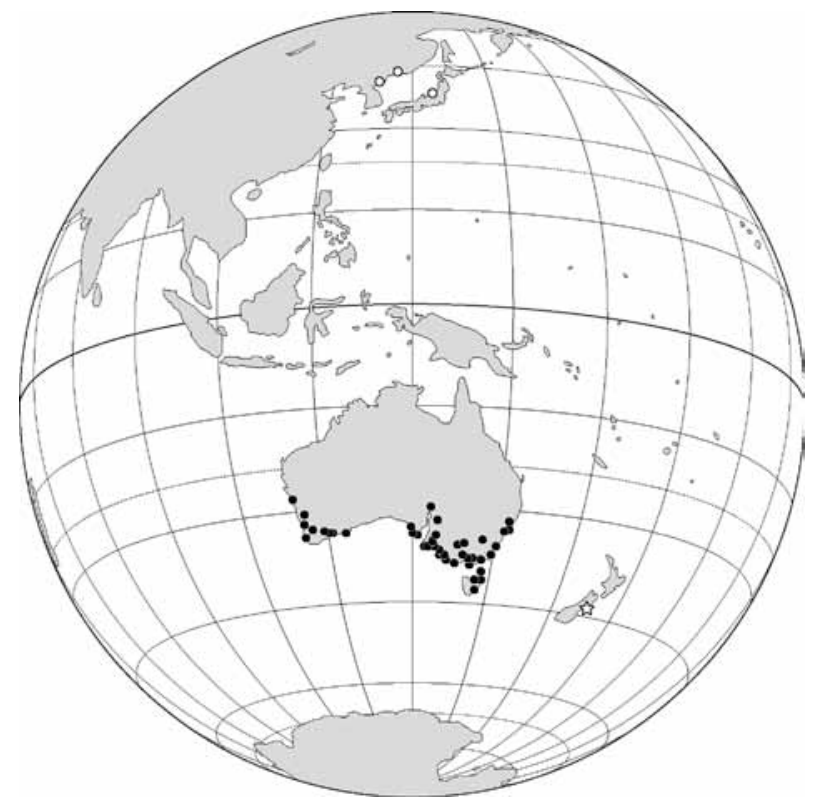

Figure 2 Distribution of Ruppia megacarpa. Solid circles are based on Jacobs \& Brocks (2009). The type and new localities are indicated with a star and open circles, respectively

5380-a); KOREA, Wonsan, 28 Jun. 1906 (KYO: Faurie no. 225; Fig. 1); RUSSIA, Hasan, Ptich'e (Talmi) Lake, 1 Jul. 2013 (Institute of Marine Biology, Far Eastern Branch of the Russian Academy of Sciences: Skriptsova-2013-001).

Note: Ruppia megacarpa is occasionally confused with $R$. cirrhosa, $R$. occidentalis ("Occidentalis" of the $R$. maritima complex; Ito et al. 2010), and R. truncatifolia. Of these, R. cirrhosa is distinguishable from $R$. megacarpa with leaf tip shape and the size of fruit; the former has round tip and $2.5 \mathrm{~mm}$ in length, while the latter has bidantate and $4-5 \mathrm{~mm}$ in length (Mason 1967). "Occidentalis" is distinguished by its (2-)8 carpels; those of R. megacarpa is usually 4 (Mason 1967, Ito et al. 2010). From R. truncatifolia, for which only vegetative rosette specimens are known, $R$. megacarpa is recognized by its zig-zag stem and well-set flowers and fruits. Note that the putative fruiting specimen of $R$. truncatifolia reported by Yamazaki et al. (2008) is a misidentification of «Occidentalis» as the specimen has round leaf tip and smaller fruit size.

\section{ACKNOW LEDGEMENTS}

The authors thank H. Nagamasu (KYO), A. Shimizu (TI), S. Gibb and I. Schonberger (CHR) for their help to find and examine Ruppia specimens. This study was partly supported by JSPS (Japan Society for the Promotion of Science) Bilateral Program with RSNZ (Royal Society of New Zealand) to YI.

\section{I T ERAT U RE CITE D}

Abràmoff, M.D., P. J. Magelhaes \& S.J. Ram 2004. Image processing with Image. Journal of Biophotonics 11: 36-42.

Beuzenberg, E.J. \& J.B. Hair 1983. Contributions to a chromosome atlas of the New Zealand flora -25 miscellaneous species. New Zealand Journal of Botany 21: 13-20.

Cook, C.D.K. 1996. Ruppiaceae. In: Aquatic Plant Book. SPB Academic Publishing, The Hague, The Netherlands, pp. 363.

Davis, J.S. \& P.B. Tomlinson 1974. A new species of Ruppia in high salinity in Western Australia. Journal of the Arnold Arboretum 55: 59-66.

Ito, Y., T. Ohi-Toma, J. Murata \& N. Tanaka 2010. Hybridization and polyploidy of an aquatic plant, Ruppia (Ruppiaceae) inferred from plastid and nuclear DNA phylogenies. American Journal of Botany 79: 1156-1167.

Jacobs, S.W.L. \& M.A. Brock 1982. A revision of the genus Ruppia (Potamogetonaceae) in Australia. Aquatic Botany 14: 325-337.

Jacobs, S.W.L. \& M.A. Brock 2009. Ruppia. In: Flora of Australia (A.J.G. Wilson, ed.). 39: 95-98.

Linnaeus, C. 1753. Ruppia. In: Species plantarum, Laurentius Salvius, Stockholm, pp. 127.

Mason, R. 1967. The species of Ruppia in New Zealand. New Zealand Journal of Botany 5: 519-531.

Yamazaki, M., M. Mochida \& Y. Kato 2008. A new record for Ruppia truncatifolia Miki (Potamogetonaceae) with fruits from Lake Tohfutsu, Hokkaido, Japan. Journal of Japanese Botany 83: 121-123 (in Japanese).

Yu, S., M.-M. Shi \& X.-Y. Chen 2014. Species diversity and distribution of Ruppia in China: Potential roles of long-distance dispersal and environmental factors. Journal of Systematics and Evolution 52: 231-239.

Zhao, L.-C. \& Z.-Y. Wu 2008 A review on the taxonomy and evolution of Ruppia. Journal of Systematics and Evolution 46: 467-478. 